\title{
REPRODUCTIVE BIOLOGY OF Astyanax janeiroensis (OSTEICHTHYES, CHARACIDAE) FROM THE UBATIBA RIVER, MARICÁ, RJ, BRAZIL
}

\author{
MAZZONI, R. ${ }^{1}$, MENDONÇA, R. S. ${ }^{2}$ and CARAMASCHI, E. P. ${ }^{2}$ \\ ${ }^{1}$ Universidade do Estado do Rio de Janeiro, Instituto de Biologia Roberto Alcântara Gomes, Ecologia, \\ Rua São Francisco Xavier, 524, Maracanã, CEP 20550-013, Rio de Janeiro, RJ, Brazil \\ ${ }^{2}$ Universidade Federal do Rio de Janeiro, Instituto de Biologia, Departamento de Ecologia, \\ C. P. 68020, Rio de Janeiro, RJ, Brazil \\ Correspondence to: Rosana Mazzoni, Universidade do Estado do Rio de Janeiro, \\ Instituto de Biologia Roberto Alcântara Gomes / Ecologia, Rua São Francisco Xavier ,524, \\ Maracanã, CEP 20550-013, Rio de Janeiro, RJ, Brazil, e-mail: mazzoni@uerj.br \\ Received October 20, 2003 - Accepted December 22, 2003 - Distributed November 30, 2005
}

(With 6 figures)

\begin{abstract}
Aspects of the reproductive biology of Astyanax janeiroensis in the Ubatiba river in Maricá, RJ, Brazil were evaluated in order to ascertain whether the strategy adopted by the species is causally related to environmental variables. Specimens were collected on a monthly basis from October 1994 to September 1995, through electrofishing. The Sex ratio was not significantly different from the expected frequency of $1: 1(\mathrm{G}=1.29$; p > 0.50); nonetheless, considering three standard length classes, significantly larger numbers of females were recorded for the higher SL class $(G=11.07 ; p<0.01)$. Size at first maturation showed no significant differences between sexes. Length-weight ratio analyses showed negative allometry for males and isometry, for females. Length structure was significantly different between sexes, suggesting that females are larger than males $(\mathrm{D}=0.027, \mathrm{p}<0.01)$. Reproductive specimens were recorded during nine months of the annual cycle. Seasonal variations of reproductive specimens belonging to two different standard length classes displayed an asynchronous behavior, with larger specimens having a longer reproductive period and smaller ones reproducing for fewer months during the annual cycle. High values of fecundity (F), varying from 3169 to 18714 oocytes, were recorded for fish of 9.1 and $10.2 \mathrm{~cm}$ lengths, respectively. The correlation between weight and number of oocytes/unit of weight was positive, indicating that larger specimens produced more eggs.
\end{abstract}

Keywords: stream-dwelling fish, coastal stream, reproductive biology.

\section{RESUMO}

\section{Biologia Reprodutiva de Astyanax Janeiroensis (Osteichthyes, Characidae) do Rio Ubatiba, Maricá, RJ}

Foram analisados aspectos da biologia reprodutiva de Astyanax janeiroensis do rio Ubatiba - Maricá, RJ, afim de discutir se a estratégia adotada possui alguma relação de causalidade com as variáveis ambientais. Os espécimens foram coletados mensalmente, entre outubro 1994 e setembro 1995, mediante pesca elétrica. A proporção sexual não diferiu significativamente do esperado 1:1 $(\mathrm{G}=1.29$; $\mathrm{p}>0.50)$; mas, considerando-se 3 classes de tamanho distintas, foi registrada diferença significativa, com predomínio de fêmeas, na classe de maior tamanho $(\mathrm{G}=11,07$; $\mathrm{p}<0,01)$. O tamanho médio da $1^{\mathrm{a}}$ maturação não apresentou diferença significativa entre os sexos. A análise da relação entre o peso e o indicou alometria negativa para os machos e isometria para as fêmeas. A estrutura de tamanho foi significativamente diferente entre os sexos sugerindo que as fêmeas alcançam tamanho superior ao dos machos $(D=0,027, p<0,01)$. Foram registrados indivíduos reprodutivos ao longo de nove meses do ciclo anual. A variação temporal de indivíduos reprodutivos, de duas classes de comprimento, indicou comportamento assincrônico com os 
exemplares de maior tamanho reproduzindo durante um maior intervalo de tempo e os exemplares menores com reprodução restrita a alguns meses do ciclo anual. Altos valores de fecundidade foram registrados, variando de 3169 a 18714 ovócitos para peixes de 9,1 a 10,2 cm, respectivamente. Análises de correlação, entre peso total e o número de ovócitos/unidade de peso, apresentou correlação positiva e indicou que os espécimes maiores produzem mais ovos.

Palavras-chave: peixes de riacho, riacho costeiro, biologia reprodutiva.

\section{INTRODUCTION}

Following the heretofore narrow perspective of fish life history (Matthews, 1998), knowledge of some reproductive traits such as sexual dimorphism, egg size, fecundity and spawning time are fundamental to understand how these traits should be adapted to maximize reproductive success in a particular environment. Nonetheless, despite the high plasticity of many life history traits, important constraints imposed by fundamental morphology or phylogeny are observed among different fish species.

Reproductive strategies of stream dwelling fish in Brazilian coastal streams have been reported at various times, with the work of Garutti (1983, 1988), Menezes \& Caramaschi (1994), Soares-Porto (1991), Aranha \& Caramaschi (1999), Mazzoni \& Petito (1999) and Mazzoni et al. (2002a) ranking among the most important.

Astyanax janeiroensis (hereinafter referred to as Astyanax) is one of the most widespread and abundant Characidae in the clear waters of the Ubatiba River. Only one coexisting Characidae (Astyanax hastatus) has been found in this stream, but its abundance is considerably lower than that of Astyanax (Mazzoni \& Lobón-Cerviá, 2000). In this paper, we describe the reproductive strategy of Astyanax. The traits analyzed here include size structure, length to weight ratio, size at first reproduction, fecundity, sex ratio and reproductive season.

\section{MATERIAL AND METHODS}

The Ubatiba river $\left(22^{\circ} 60^{\prime} \mathrm{S}\right.$ and $\left.42^{\circ} 48^{\prime} \mathrm{W}\right)$ consists of a small coastal fluvial system of the Brazilian East Basin in the state of Rio de Janeiro. This river flows through meadows deforested for farming and cattle ranching, although patches of pristine Atlantic forest are still common on the slopes of the surrounding rocky hills. Water level is regulated by rainfall $\left(\sim 1500 \mathrm{~mm} \mathrm{yr}^{-1}\right)$, but the system's main physical characteristics are the sudden spates that stress local habitats and the absence of seasonality in the hydric regime (Mazzoni \& Lobón-Cerviá, 2000).

The specimens investigated in this study were collected by electrofishing (1000 W, 2-3 A) between October 1994 and September 1995 in a monthly basis (see more detailed information about the sampling methodology in Mazzoni et al., 2000b).

Sampled fish were packed in ice for transportation, processed in the laboratory and the following data obtained: i) standard length (SL - 0.1mm); ii) total weight (WT - $0.01 \mathrm{gr}$ ); iii) sex; and iv) gonadal weight (WG - $0.01 \mathrm{gr}$ ).

Prior to preservation, the ovaries/testes were classified according to a macroscopic scale of gonadal development, taking into account the vascular irrigation and the relative occupation in the abdominal cavity, for both sexes; for females, the size and color of oocytes were also recorded, and for males, sperm release when pressing the abdomen was recorded. According to these characteristics, the following classification was considered: females - immature, mature 1 , mature 2 , ripe and spawned; males - immature, mature 1, mature 2, ripe and spent. The ovaries were then fixed in modified Gilson's fluid (Vazzoler, 1981) for oocyte measurements and counts.

Ovaries preserved in Gilson's fluid were stored for two weeks and shaken periodically to promote oocyte release. Oocytes were then cleaned by changing the alcohol and removing the ovarian membranes, and stored in a $70^{\circ} \mathrm{GL}$ alcohol solution. Fecundity (F) was determined according to Bagenal \& Braum (1971) after all the vitellogenic oocytes from 25 ripe ovaries were counted and correlated to SL, WT and WT/number oocytes per unit of WT (WT/F/gr).

Standard length structure was determined by the number of individuals in different SL classes, while sexual dimorphism for length was 
tested by applying the Kolmogorov-Smirnov test on two samples. The SL/WG relationship was established from the LN transformed data of SL and WT, using the Minimum Square Method; differences between sexes were tested with the angular coefficients test. The size at first maturation $\left(\mathrm{SL}_{50}\right)$ was determined according to the methodology presented in Vazzoler (1981). All the aforementioned analyses were made separately on males and females.

The sex ratio was determined for the whole sample and for the three SL classes, established according to $\mathrm{SL}_{50}$, and the bias in the proportion of individuals of each sex was tested by the log-likelihood ratio ( $\mathrm{G}$ test). The reproductive season was tested through the temporal distribution of mean GI (Gonadosomatic Index - GI $=$ WG $/$ WT $* 100$ ) and ovarian/testis maturation stages. For the latter, the maturation stages were rearranged as follows: Immature young fish without developed gonads and SL equal to or less than $\mathrm{SL}_{50}$; Non-reproductive - adult fish, $\mathrm{SL}$ of more than $\mathrm{SL}_{50}$, in mature, mature 1 and 2 and recovering gonads; and Reproductive - adult fish, $\mathrm{SL}$ of more than $\mathrm{SL}_{50}$, with ripe and spawned/spent gonads. The seasonal pattern of reproduction was tested based on the temporal variation of the mean GI of three different SL classes.

\section{RESULTS}

A total of 308 specimens were analyzed, 164 females and 144 males. The sex ratio presented no significant difference from the expected $1: 1$ ratio $(\mathrm{G}=1.29 ; \mathrm{p}>0.50)$; however, considering the three SL classes, the higher class showed a significant difference (Fig. 1; Table 1). The standard length distribution differed between the sexes $(D=0.027$, $\mathrm{p}<0,01)$, indicating that males and females reached $11.4 \mathrm{~cm}$ (mean $\mathrm{SL}=6.81 \mathrm{~cm}$ ) and $10.6 \mathrm{~cm}$ (mean $\mathrm{SL}=7.16 \mathrm{~cm}$ ), respectively (Fig. 2). The lengthweight relationship for Log transformed data of SL and WT showed significant positive correlations: females - i) females: LNWT $=3.04$ LNSL - 3.68; $\mathrm{r}=0.98 ; \mathrm{p}<0.01$; and ii) males: $\mathrm{LNWT}=2.73$ LNSL - 3.17; $r=0.98 ; \mathrm{p}<0.01$. Between sexes differences for the lenght-relationship were also registered $(\mathrm{t}=4.00 ; \mathrm{df}=285 ; \mathrm{p}<0.05)$

The onset of sexual maturity was determined as the SL class in which $50 \%$ of specimens were adult; males and females presented no difference for this characteristic, and $5.5 \mathrm{~cm}$ was found to be the size of Astyanax at first maturation (Fig. 3).

Reproductive specimens occurred throughout the year except for May to July, with a higher incidence between November and March (Fig. 4). The same results were found by monthly distribution of GI (Fig. 5). A seasonal analysis of reproduction of different SL classes specimens indicated that adult specimens longer than $9.0 \mathrm{~cm}$ were responsible for this pattern, since they were reproducing over an extended period. Smaller (= younger $)$ specimens displayed markedly seasonal reproduction, since breeding specimens occurred only during some spring and summer months, from October to February (Fig. 6).

Astyanax fecundity (F) showed a positive correlation with length (SL) - F $=4543 \mathrm{SL}$ $33456, \mathrm{r}=0.84, \mathrm{n}=20 ; \mathrm{p}<0.01$ and weight $(\mathrm{WT})$ $-\mathrm{F}=551 \mathrm{WT}-4117, \mathrm{r}=0.89, \mathrm{n}=20 ; \mathrm{p}<0.01$, varying from 3169 to 18714 oocytes, respectively, for 9.1 and $10.2 \mathrm{~cm}$ long fish. A correlation analysis of WT and number of oocytes/unit of WT (WT/F/gr) showed a positive correlation $(\mathrm{WT} / \mathrm{F} / \mathrm{gr}=8.1607 \mathrm{WT}+165.82, \mathrm{r}=0.57, \mathrm{n}=20$; $\mathrm{p}<0.01$ ), indicating that larger specimens are more efficient in producing eggs.

\section{DISCUSSION}

Nikolsky (1963) referred to sexual differences in body size and length-weight relationship as the most frequent form of sexual dimorphism among fish. Among females, a large size is favored because it increases fecundity, whereas male size is affected by sexual selection, with bigger males enjoying a reproductive advantage (Greenwood \& Wheeler, 1985; Parker, 1982; Shine, 1990). With

TABLE 1

Number of females and males, sex ratio, $\chi^{2}$ and significance level for three different SL classes of adult Astyanax janeiroensis.

\begin{tabular}{|c|c|c|c|}
\hline SL classes $(\mathbf{c m})$ & $\mathbf{2 . 5 - 5 . 5}$ & $\mathbf{6 . 5 - 8 . 5}$ & $\mathbf{9 . 5 - 1 1 . 5}$ \\
\hline Female & 52 & 83 & 87 \\
\hline Males & 36 & 98 & 27 \\
\hline Sex ratio & $1: 1$ & $1: 1$ & $3.2: 1$ \\
\hline $\mathrm{G}$ & 2.92 & 1.24 & 11.07 \\
\hline $\mathrm{p}$ & $>0.50$ & $>0.50$ & $<0.01$ \\
\hline
\end{tabular}




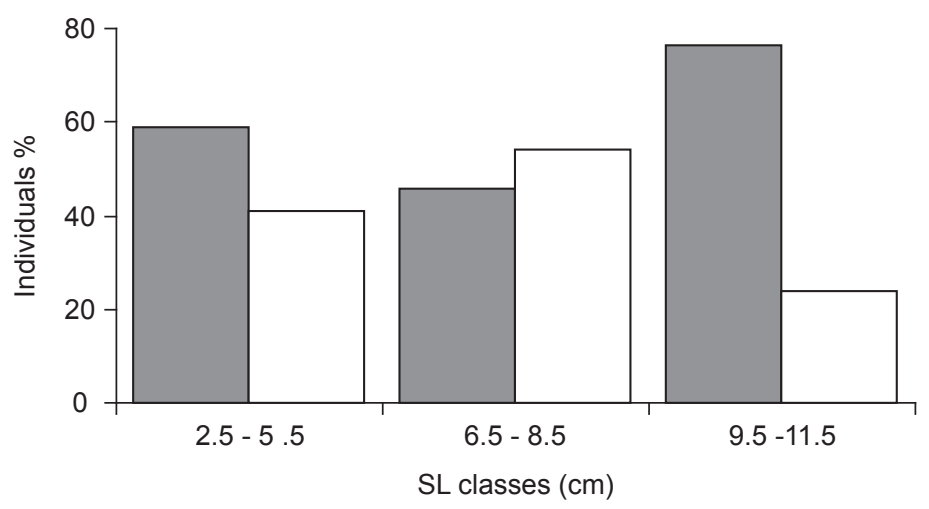

Fig. 1 - Sex ratio of Astyanax janeiroensis considering three different Standard Length classes. Grey bars correspond to females and white bars to males.

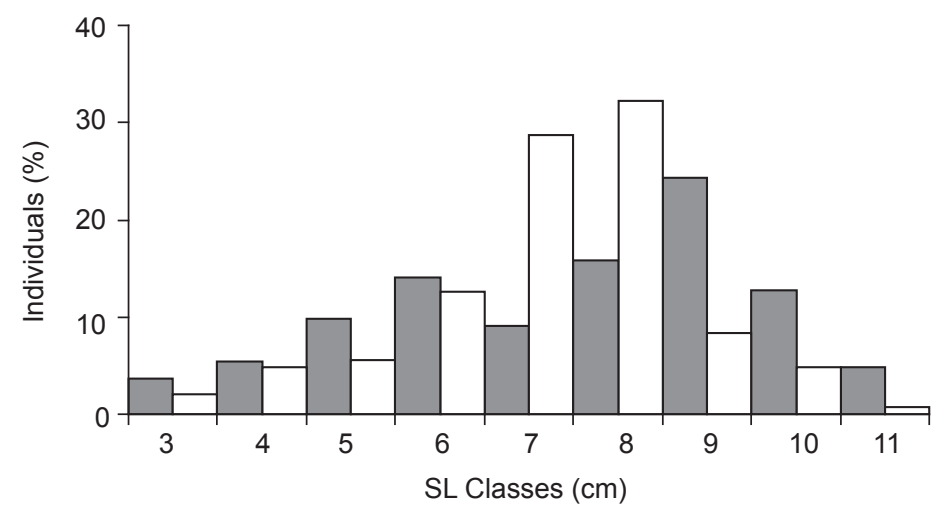

Fig. 2 - Standard length distribution of males and females Astyanax janeiroensis from the Ubatiba fluvial system, MaricáRJ. Grey bars correspond to females and white bars to males.

competitive behavior absent during reproductive events, Astyanax species are pelagic spawners normally reproducing in school formation during up-stream movements (Breeder \& Rosen, 1966; Mazzoni \& Iglesias-Rios, 2004), and the increase in potential fecundity among larger females may explain the differences in length structure observed here.

The onset of sexual maturity plays an important role, shedding light on the life-history adopted by a species during its evolution (Stearns, 1976; Lessels, 1991; Stearns \& Crandal, 1984). It is an accepted fact that the optimal size for the first reproduction depends upon many factors, including the relative allocation of energy between somatic and gonadic growth (Mann et al., 1984). The benefits of larger specimens will be countered by opposing selective forces, such as survivorship and potential reproduction, for the longer maturity is delayed the lesser the chance of surviving to leave descendants (Ross, 1986).

A. janeiroensis attained sexual maturity at $5.5 \mathrm{~cm}$, which is a smaller size than that found by Barbieri (1992) for Astyanax scabripinnis paranae and Agostinho et al. (1984) for Astyanax bimaculatus (Paraná basin), although these three species attain the same size. The interpretation of the selective forces acting on Astyanax suggests that reproductive precocity may be related to an adaptive behavior to compensate for the stochastic mortality imposed by the unstable hydrology of the Ubatiba River system. Such an adaptation may explain the success of small species such as Deuterodon sp. (Mazzoni \& Petito, 1999) and 


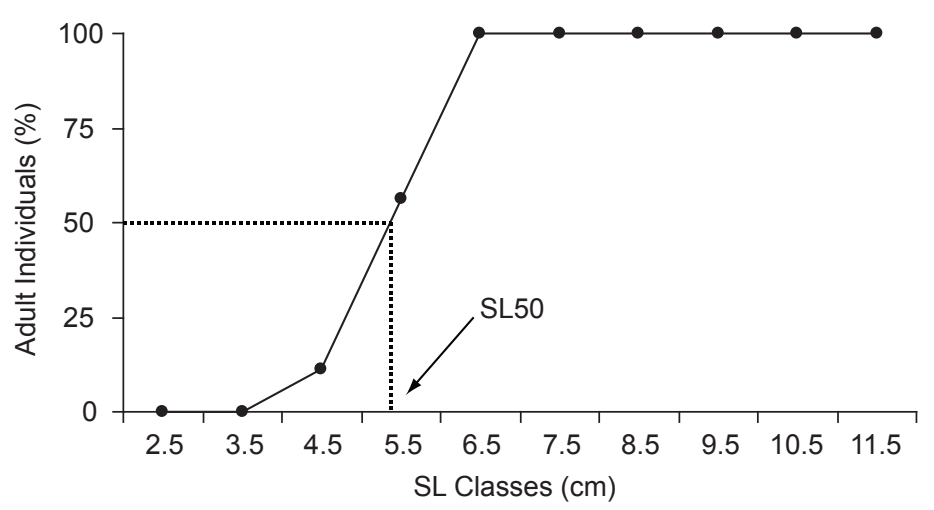

Fig. 3 - Standard length distribution of adult specimens of Astyanax janeiroensis from the Ubatiba fluvial system, MaricáRJ. $\mathrm{SL}_{50}$ means standard length at sexual maturity.

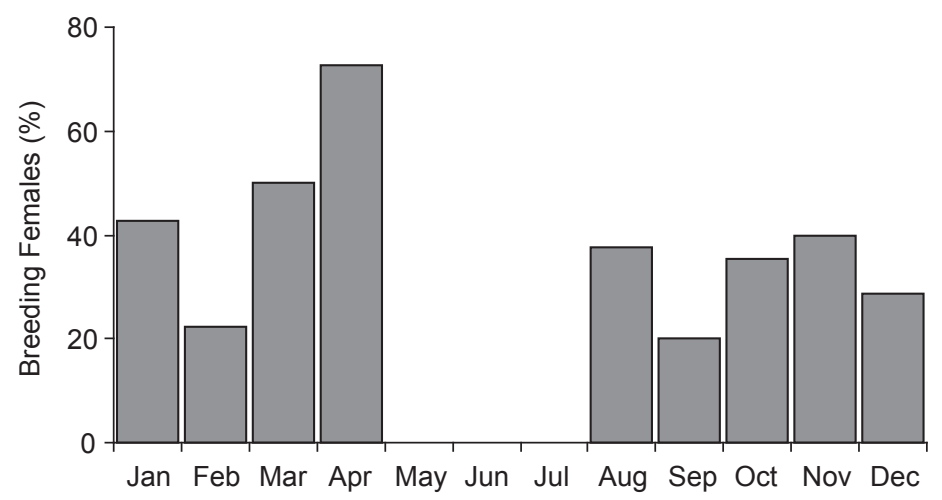

Fig. 4 - Temporal variation of reproductive specimens of Astyanax janeiroensis from the Ubatiba fluvial system, Maricá-RJ.

Characidium sp. (Mazzoni et al., 2002a) when considering an unpredictable environment like that of the Ubatiba River.

The prolonged breeding season found in this study can be explained by the same rationale and was also found for other species from the Ubatiba River (Menezes \& Caramaschi, 1994; Mazzoni \& Petito; 1999; Mazzoni et al.; 2002a; Mazzoni \& Iglesias-Rios, 2002). In this breeding pattern, we found that adult specimens are nonseasonal breeders, whereas younger specimens are markedly seasonal breeders, with reproduction determining an asynchronous pattern of reproduction. Hyndes et al. (1992) attributed delayed reproduction among young specimens to delayed maturation of specimens reproducing for the first time. According to Nikolsky (1963), intrapopulation asynchrony may be explained as evasion for competition for breeding places. Mazzoni \& Caramaschi (1995) found the same holds true for two sympatric populations of Hypostomus. Considering that Astyanax are pelagic spawners, we believe that Hyndes et al.'s (1992) proposition is probably more accurate in the case studied here.

Fecundity was shown to be positively correlated with female weight and length. Nonetheless, an analysis of the correlation between weight and number of eggs per unit of weight revealed that larger females are able to produce more eggs per unit of body mass, indicating that big fish produce more offspring than small fish.

The overall reproductive strategy of $A$. janeiroensis suggests that a high energy budget is allocated to reproduction, mainly by bigger females, 


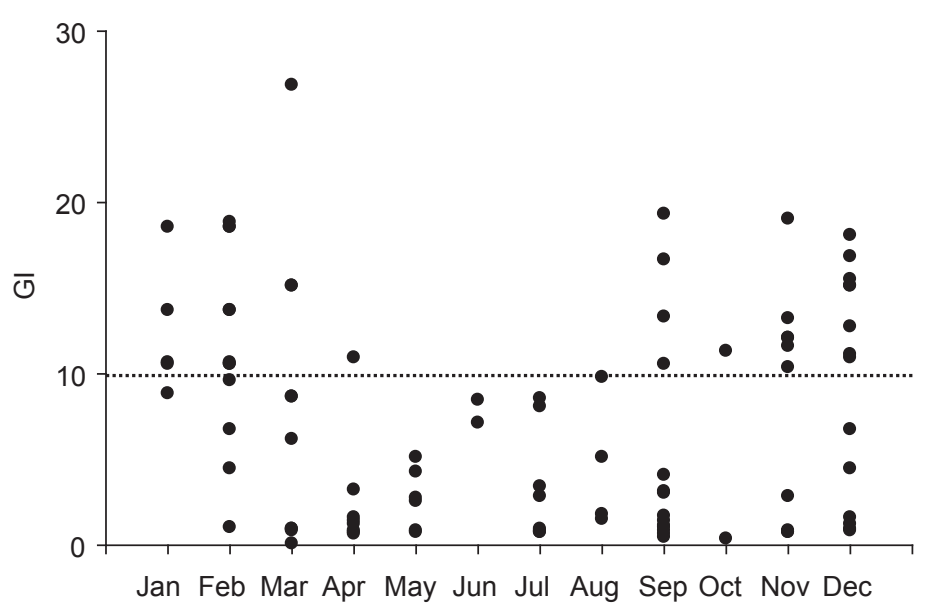

Fig. 5 - Temporal variation of Gonadosomatic Index (GI) of Astyanax janeiroensis from the Ubatiba fluvial system, MaricáRJ. Points below doted line indicate non reproductive specimens.

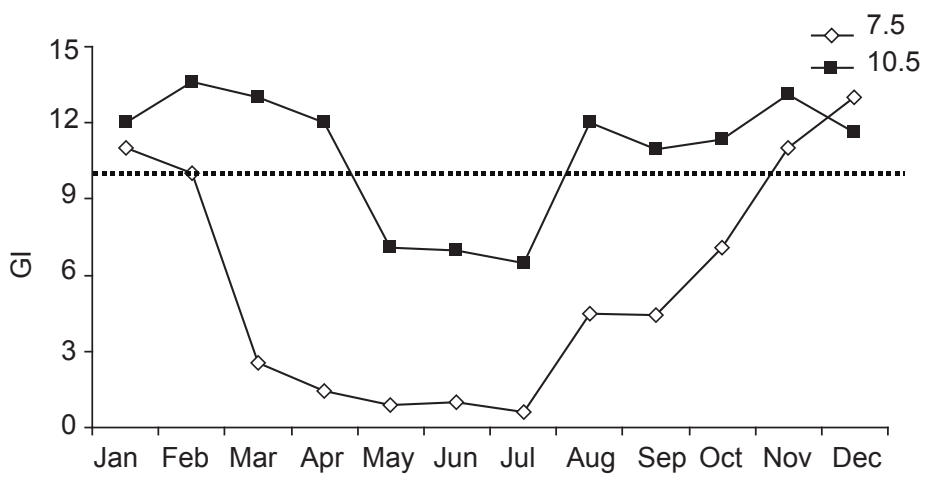

Fig. 6 - Temporal variation of mean Gonadosomatic Index (GI) of two standard length classes. 7.5 and 10.5 are mid points of classes $6.5-8.9 \mathrm{~cm}$ and $9.0-11.0 \mathrm{~cm}$.

in order to compensate for the unpredictable hydrological conditions prevailing in the Ubatiba River.

Acknowledgments - We thank the members of the Fish Ecology Laboratories of Universidade do Estado do Rio de Janeiro and Universidade Federal do Rio de Janeiro for helping with the field work and Ricardo Iglesias-Rios for his valuable suggestions on the manuscript. This work was funded by CNPQ / Projeto Integrado - 521597/95-1 (Brazil) and FAPERJ / APQ1 - E-26/170.591/95 (Brazil), and is part of an Introduction to Science study by Rebeca de Saules Mendonça.

\section{REFERENCES}

Agostinho, C. A., MOLinARI, S., AgOstinho A., \& VERANI, J., 1984, Ciclo reprodutivo e primeira maturação sexual de fêmeas do lambari Astyanax bimaculatus (L.)
(Osteichtyes-Characidae) do rio Ivaí. Estado do Paraná. Revista Brasileira de Biologia, 44(1), 31-36.

ARANHA, J. M. \& CARAMASCHI, E. P., 1999, Estrutura populacional, aspectos da reprodução e alimentação dos Cyprinodontiformes (Osteichthyes) de um riacho do sudeste do Brasil. Revista Brasileira de Zoologia, 16: 637-651.

BAGENAL, T. B. \& BRAUM, E., 1971, Eggs and Early Life History. In: RICKER, W. E. (ed), Methods for Assessment of Fish Production in Fresh Waters, Blackwell Scientific Publications. IBP n. 3. pp. 166-198.

BARBIERI, G., 1992, Biologia de Astyanax scabripinis paranae (Characiformes, Characidae) do Ribeirão do Fazzari. São Carlos. Estado de São Paulo. I. Estrutura Populacional e Crescimento. Revista Brasileira de Biologia, 52 (4): 579-588.

BARBIERI,G.; SANTOS, M. V. R. \& SANTOS, J. M., 1982, Época de reprodução e relação peso/comprimento de duas 
espécies de Astyanax (Pisces, Characidae). Pesquisas Agropecuárias Brasileira, 17 (7): 1057-1065.

BREDER, C. M. \& ROSEN, D. E., 1966, Modes of Reproduction in Fishes. Natural History Press, Graden City. 941 p.

GARUTTI, V., 1983, Distribuição longitudinal da ictiofauna do córrego Barra Funda, bacia do Paraná. Dissertação de Mestrado, Universidade de São Paulo. 172 p.

GARUTTI, V., 1988, Distribuição longitudinal da ictiofauna em um córrego da região noroeste do estado de São Paulo, bacia do rio Paraná. Rev. Brasil. Biol., 48 (4): 747-759.

GREENWOOD, P. J. \& WHEELER, P., 1985, The evolution of sexual size dimorfism in birds and mammals: a hot blooded hypothesis. In- Evolution: Essays in Honour of John Maynard Smith, eds. P.J. Greenwood; P.H. Harvey \& M. Slaktin. Cambridge University Press, Cambridge. pp. 287-299.

HYNDES, G. A.; NEIRA, F. J. \& POTTER, I. C., 1992, Reproductive biology and early life history of the marine teleost Platycephalus speculator Klunzinger (Platycephalidae) in a termperate Australian estuary. Journal of Fish Biology, 40: 859-874.

LESSELS, C. M., 1991, The evolution of life histories. In: KREBS, J.R. \& DAVIES, N.B. (eds) Behavioural Ecology. Blackwell Scientific Publications, London. 32-68 p.

MANN, R. H. K.; MILLS, C. A. \& CRISP, D. T., 1984, Geographical variation in the life-history tactics of some species of freshwater fishes. In: POTTS, G. W. \& WOOTTON, R.J. (ed) Fish Reproduction: Strategies and Tactics, Academic Press, London, pp. 171-186.

MATTHEWS, W. J., 1998, Patterns in Freshwater Fish Ecology. Chapman \& Hall, Oxford. 756 p.

MAZZONI, R. \& CARAMASCHI, E. P., 1995, Size structure, sex ratio and onset of sexual maturity of two species of Hypostomus Lacépède, (Osteichthyes, Loricariidae). Journal of Fish Biology, 47: 841-849.

MAZZONI, R. \& PETITO, J. T., 1999, Reproductive biology of a Tetragonopterinae (Osteichthyes, Characidae) of the Ubatiba fluvial system, Maricá - RJ. Brazilian Achieves of Biology and Technology, 42(4): 455-461.

MAZZONI, R. \& LOBÓN-CERVIÁ, J., 2000, Longitudinal structure, density and production rates of a Neotropical stream fish assemblage: the river Ubatiba in the Serra do Mar (South-East Brazil). Ecography, 23: 588-602.
MAZZONI, R., FENERICH-VERANI, N. \& CARAMASCHi, E. P., 2002(a), Reproductive biology of a Characidinae (Osteichthyes, Characidae) from the Ubatiba River, Maricá - RJ. Brazilian Journal of Biology, 62 (3): 487-494.

MAZZONI, R.; FENERICH-VERANI, N. \& CARAMASHI, E.P., 2000(b), Electrofishing as a sampling technique for coastal stream fish populations in the Southeast of Brazil. Revista Brasileira de Biologia, 60: 205-216.

MAZZONI, R. \& IGLESIAS-RIOS, R., 2002, Environmentally Related Life History Variations in Geophagus brasiliensis. Journal of Fish Biology, 61: 1606-1618.

MAZZONI, R. \& IGLESIAS-RIOS, R., 2004, Longitudinal segregation of Astyanax janeiroensis in the Rio Ubatiba: A Neotropical stream of south-east Brazil. Ecology of Freshwater Fish, 13: 231-234.

MENEZES, M. S. \& CARAMASCHI, E. P., 1994, Características reprodutivas de Hypostomus gr. punctatus do rio Ubatiba, Maricá - RJ (Osteichthyes, Siluriformes). Revista Brasileira de Biologia, 54: 503-513.

NIKOLSKY, G. V., 1963, The Ecology of Fishes. Acad. Press, London, pp. 352 p.

PARKER, G. A., 1982, Why are there so many tiny sperm? Sperm competition and the maintenance of two sexes. Journal of Theoretical Biology, 96: 281-294.

ROFF, D. A., 1986, Predicting body size with life history models. Bioscience, 36: 316-323.

SHINE, R., 1990, Proximate determinants of sexual differences in body size. American Naturalist, 135: 278-283.

SOARES-PORTO, L. M., 1991, Distribuição longitudinal, dieta alimentar e ciclo reprodutivo de Pimelodella lateristriga (Osteichthyes, Siluroidei) no rio Ubatiba Maricá, Rio de Janeiro. Dissertação de Mestrado, Museu Nacional do Rio de Janeiro, UFRJ, $156 \mathrm{p}$.

STEARNS, S. C., 1976, Life history tactics: a review of the ideas. Quarterly Review in Biology, 51: 3-47.

STEARNS, S. C. \& CRANDALL, R. E., 1984, Plasticity for age and size at sexual maturity: a life-history response to unavoidable stress. In: POTTS, G.W. \& WOOTTON, R.J. (ed), Fish Reproduction: Strategies and Tactics, Academic Press, London, pp. 13-34.

VAZZOLLER, A. E. A. DE M., 1981, Manual e métodos para estudos biológicos de populações de peixes. Reprodução e Crescimento. Brasília, CNPq / Programa Nacional de Zoologia. $127 \mathrm{p}$. 